\title{
Correction to: A digital health peri- operative cognitive-behavioral intervention to prevent transition from acute to chronic postsurgical pain in adolescents undergoing spinal fusion (SurgeryPal ${ }^{\mathrm{TM}}$ ): study protocol for a multisite randomized controlled trial
}

Jennifer A. Rabbitts ${ }^{1,2^{*}}$, Chuan Zhou ${ }^{3,4}$, Rocio de la Vega ${ }^{5}$, Homer Aalfs ${ }^{3}$, Caitlin B. Murray ${ }^{2,3}$ and

Tonya M. Palermo $2,3,4$

Correction to: Trials 22, 506 (2021)

https://doi.org/10.1186/s13063-021-05421-3

Following the publication of the original article [1], we were notified of an error in Fig. 1, the embedded SPIRIT diagram. In the first horizontal blue box, the text should read: "Phase 1: Pre-operative treatment (4 weeks)".

The original paper has been corrected.

\section{Author details}

'Center for Clinical and Translational Research (CCTR), Seattle Children's Hospital, 4800 Sand Point Way NE MB.11.500.3, Seattle, WA 98105, USA. ${ }^{2}$ Department of Anesthesiology and Pain Medicine, University of Washington, 1959 NE Pacific St, Seattle, WA 98195, USA. ${ }^{3}$ Center for Child Health Behavior and Development (CHBD), Seattle Children's Hospital, 1920 Terry Avenue, Seattle, WA, USA. ${ }^{4}$ Department of Pediatrics, University of Washington, 4800 Sand Point Way NE, Seattle, WA 98105, USA. ${ }^{5}$ Department of Psychology, University of Málaga, Campus de Teatinos, s/n, 29071 Málaga, Spain.
Published online: 21 September 2021

\section{Reference}

Rabbitts, et al. A digital health peri-operative cognitive-behavioral intervention to prevent transition from acute to chronic postsurgical pain in adolescents undergoing spinal fusion (SurgeryPal ${ }^{\top \mathrm{M}}$ ): study protocol for a multisite randomized controlled trial. Trials. 2021;22:506. https://doi.org/1 0.1186/s13063-021-05421-3.

The original article can be found online at https://doi.org/10.1186/s13063021-05421-3.

* Correspondence: jennifer.rabbitts@seattlechildrens.org

${ }^{1}$ Center for Clinical and Translational Research (CCTR), Seattle Children's Hospital, 4800 Sand Point Way NE MB.11.500.3, Seattle, WA 98105, USA

${ }^{2}$ Department of Anesthesiology and Pain Medicine, University of Washington, 1959 NE Pacific St, Seattle, WA 98195, USA

Full list of author information is available at the end of the article

C C The Author(s). 2021 Open Access This article is licensed under a Creative Commons Attribution 4.0 International License, which permits use, sharing, adaptation, distribution and reproduction in any medium or format, as long as you give appropriate credit to the original author(s) and the source, provide a link to the Creative Commons licence, and indicate if changes were made. The images or other third party material in this article are included in the article's Creative Commons licence, unless indicated otherwise in a credit line to the material. If material is not included in the article's Creative Commons licence and your intended use is not permitted by statutory regulation or exceeds the permitted use, you will need to obtain permission directly from the copyright holder. To view a copy of this licence, visit http://creativecommons.org/licenses/by/4.0/. The Creative Commons Public Domain Dedication waiver (http://creativecommons.org/publicdomain/zero/1.0/) applies to the data made available in this article, unless otherwise stated in a credit line to the data. 